\title{
Laser Cutting of Square Blanks in Stainless Steel-304 Sheets: HAZ and Thermal Stress Analysis
}

(Pemotongan Laser Segi Empat Kosong dalam Lembaran Keluli Kalis Karat-304: HAZ dan Analisis Tegasan Termal)

\author{
A.M. Sifullah, Khaled I. AhMED, Y. NUKMAN*, M.A. HASSAN \& A. HosSAIN
}

\begin{abstract}
Laser cutting is a non-traditional cutting process and cutting of square blank in stainless steel-304 sheets cause heat affected zone (HAZ) and thermal stress. Formation of HAZ is undesirable and excessive stress cause surface defects. Thus, it is necessary to analyze them intensively. The process of laser cutting is a complex thermo-mechanical process. Hence, in this study a thermo-mechanical finite element model has been introduced by ANSYS to predict the temporal variation together with thermal stress and width of heat affected zone (HAZ). CO laser is used to cut $10 \times 10 \mathrm{~mm}$ square blank in a $3 \mathrm{~mm}$ thick stainless steel-304 sheet. Optical microscope and SEM are used to analyse the parametric effect on surface quality at the cutting edge. The results showed that maximum temperature at the cutting edge is about to melting temperature and independent to laser power and cutting speed. Importantly, cutting speed has significant effect on rate of temperature variation. Moreover, the width of HAZ increases with the increase of laser power and decrease of cutting speed. However results of ANOVA suggested that laser power is the most significant parameter having $64.21 \%$ of contribution to width of HAZ. Furthermore, maximum stress is observed at the corner; which is supported by SEM analysis.
\end{abstract}

Keywords: Finite element analysis; heat affected zone; laser blanking; stainless steel-304; thermal stress

\section{ABSTRAK}

Pemotongan laser adalah satu proses pemotongan bukan tradisi dan memotong kepingan keluli kalis karat-304 segi empat kosong boleh menyebabkan terjadinya zon terjejas haba (HAZ) dan tekanan termal. Pembentukan HAZ tidak diingini dan tekanan berlebihan akan menyebabkan kecacatan permukaan. Oleh itu, adalah perlu untuk menganalisis perkara ini secara intensif. Tetapi proses pemotongan laser adalah proses termo-mekanik kompleks. Oleh itu, dalam kajian ini, model unsur terhingga termo-mekanik telah diperkenalkan menggunakan ANSYS untuk meramalkan perubahan variasi sementara bersama dengan tekanan termal dan lebar zon terjejas haba (HAZ). CO laser digunakan untuk memotong 10 $\times 10$ mm kepingan keluli kalis karat-304 segi empat kosong dengan kelebaran 3 mm. Mikroskop optik dan SEM digunakan untuk menganalisis kesan parametrik pada kualiti permukaan di pinggir pemotongan. Keputusan menunjukkan bahawa suhu maksimum di pinggir pemotongan adalah berkadaran dengan suhu takat lebur dan berkadaran dengan kuasa laser dan kelajuan pemotongan. Oleh itu, kelajuan pemotongan mempunyai kesan yang besar ke atas kadar perubahan suhu. Tambahan pula, lebar HAZ meningkat dengan peningkatan kuasa laser dan penurunan kelajuan pemotongan. Walau bagaimanapun, keputusan ANOVA mencadangkan bahawa kuasa laser adalah parameter yang paling penting mempunyai $64.21 \%$ daripada sumbangan untuk lebar HAZ. Tambahan pula, tekanan maksimum diperhatikan berlaku di bahagian sudut juga disokong oleh analisis SEM.

Kata kunci: Analisis model terhingga; kalis karat-304; pemblankan laser; tegasan termal; zon terjejas haba

\section{INTRODUCTION}

The process of laser cutting is thermal in nature. During laser cutting highly concentrated laser beam is used as a heat source to melt or vaporize the material and assist gas is used to blown away the molten material from the workpiece (Yusoff et al. 2008). Consequently desired cutting with narrow cut-kerf is taken place. However, stainless steel-304 is austenitic steel, having significant proportion of chromium (18.28\%), nickel (8.48\%), carbon $(0.055 \%)$, manganese $(1.00 \%)$, phosphorus $(0.029 \%)$, sulphur $(0.005 \%)$ and silicon $(0.6 \%)$. Thus, melting and re-solidification associated with laser cutting of stainless steel-304 introduces grain refinement, carbide or sulphide formation and thermal stress near the cut-kerf, which cause unwanted heat affected zone (HAZ) and surface cracks (Jamshidi Aval et al. 2009; Masumoto et al. 1990). Due to the complexity of laser cutting process different numerical, analytical and intelligent models have been introduced. Among them, finite element method (FEM) is more popular and suitable to analyse the steady and transient 2D/3D heat flow problem like laser cutting. Because it allows to set nonlinear boundary conditions close to reality (Parandoush \& Hossain 2014). The first 2-D FEM model for HAZ analysis was proposed by Sheng and Joshi (1995). They used timetemperature relationship to measure the width of HAZ of stainless steel-304 (Sheng \& Joshi 1995). After that 
transient thermal model for laser assisted machining (LAM) was proposed by Anderson and Shin (2006). Germain et al. (2007) also proposed a simulation model to plot the HAZ profile in AISI 52100 by using commercial FEA software Abaqus/Standard ${ }^{\circledR}$ and validated with experimental result. Khan and Yilbas (2004) presented a numerical model for thermo-mechanical analysis by using finite element method (FEM) to cut sheet metal. Nyon et al. (2012) also proposed an 3-D FEM model for inert gas laser cutting on Inconel 718 and found that laser power and speed are the most significant parameter in laser cutting. Due to lack of computational power most of the numerical models of the laser cutting proposed by researchers are straight line cutting. Comparatively, few numerical models have been developed to describe the effects of laser parameters on HAZ and thermal stresses in terms of different shape of workpiece. Yilbas et al. $(2014,2009)$ proposed FEM model for thermo-mechanical analysis during laser blanking of circular and triangle shapes.

In this study an experimentally validated coupled thermo-mechanical finite element model has been introduced by ANSYS in order to explain the laser cutting mechanism of $\mathrm{CO}_{2}$ laser blanking of square samples. Optical microscope is used to measure the width of HAZ and XRD is used to identify the presence of carbide, sulphide near the cutting edge, which declares the presence of HAZ. However, scanning electron microscope (SEM) is used to examine the morphological and metallurgical changes along the cut surface.

\section{MATERIALS AND METHODS}

In the present study AMADA FO-2412 $\mathrm{CO}_{2}$ laser machine, with AMNC CNC control are used to perform the experiment. With $127 \mathrm{~mm}$ focal lens, $0.50 \mathrm{~mm}$ diameter laser beam is created. The assist gas nitrogen is impinged on the surface of workpiece from a conical nozzle at a pressure of 0.9 psi. Three different laser powers and speeds are used to cut $10 \times 10 \mathrm{~mm}$ square blanks from $3 \mathrm{~mm}$ thick stainless steel-304 sheet. The details dimension and laser path is shown in Figure 1. For better understanding eight different points (A,B.C.D.E.F.G.H) are considered along the laser path (Figure 1). The cutting starts from point $\mathrm{A}$.

\section{MATHEMATICAL DESCRIPTION AND BOUNDARY CONDITION}

The proposed thermo-mechanical model is devoloped by considering the following assumptions: The material is homogeneous and laser beam focused perpendicularly. With an appropriate depth of focus, the laser energy density is equal along the thickness of the work piece. Laser cutting is conducted at atmospheric condition and the effect of radiation heat loss is negligible.

From the Fourier's law, the mathematical model for time dependant 3D transient heat conduction for laser cutting can be written as follows (Yang et al. 2010).

$$
\rho c_{p}\left(\frac{\partial T}{\partial t}+v \frac{\partial T}{\partial x}\right)=\frac{\partial}{\partial x}\left(k \frac{\partial T}{\partial x}\right)+\frac{\partial}{\partial y}\left(k \frac{\partial T}{\partial y}\right)+\frac{\partial}{\partial z}\left(k \frac{\partial T}{\partial z}\right)+S_{0},
$$

where $k, c_{p}, \rho, v$ are conductivity, specific heat, density and cutting speed, respectively. The irradiated laser beam is Gaussian in nature, can be explained by (2).

$$
S_{0}=I_{0} A e^{-\delta z} e\left(-\frac{\left(x^{2}+y^{2}\right)}{r^{2}}\right)
$$

where $I_{o}, A, \delta, r$ are laser intensity, absorbtivity, depth of penetration and beam radious, respectively. The value of absobtivity of stainless steel-304 varies from 0.20 to 0.645 (Boyden \& Zhang 2006; Mazumder \& Steen 1980; Steen et al. 2003; Tan 2005). In this study the average value of absorbtivity 0.50 is considered.

Initial condition of the experimental environment is explained by (3).

$$
T(x, y, z, 0)=T_{a}
$$

where $T_{a}$ is ambient temperature $\left(30^{\circ} \mathrm{C}\right)$. At the top surface assist gas $\mathrm{N}_{2}$ strikes with high pressure and heat loss is expressed by (4).

$$
q_{\text {top }}=h_{\text {forceconv }}\left(T_{s}-T_{a}\right),
$$

where $T, h_{\text {forceconv }}$ are surface temperature and force heat transfer coefficient $\left(3000 \mathrm{WK}^{-1} \mathrm{~m}^{-2}\right)$, respectively (Yilbas

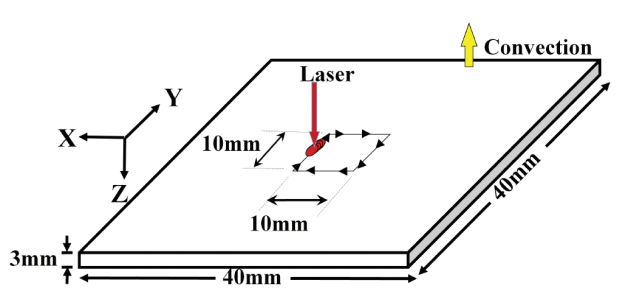

(a)

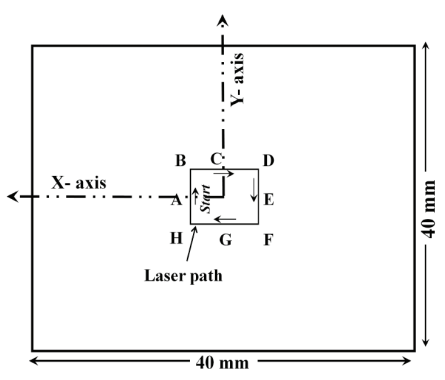

(b)

FIGURE 1. Schematic diagram of experimental setup 
\& Davies 1990). Assuming free convection to atmosphere, the boundary condition at the bottom and lateral surfaces are expressed by (5).

$$
q_{\text {other }}=h_{\text {freconv }}\left(T_{s}-T_{a}\right) \text {, }
$$

where, $h_{\text {freeconv }}$ is heat transfer coefficient at atmospheric condition $\left(15 \mathrm{WK}^{-1} \mathrm{~m}^{-2}\right)$. It is also assumed that any heated point on the material surface is blown away from the work piece by assist gas as soon as its temperature reaches the melting point. Thus, the cutting is taken place avoiding further increase in temperature beyond the melting point. The process of laser cutting is a combination of heating and rapid cooling. The total strain vector for laser cutting can be expressed as follows:

$$
\{\varepsilon\}=\left\{\varepsilon^{e} l\right\}+\left\{\varepsilon^{t h}\right\}+\left\{\varepsilon^{p l}\right\},
$$

where $\{\varepsilon\},\left\{\varepsilon^{e} l\right\},\left\{\varepsilon^{\text {th }}\right\}$ and $\left\{\varepsilon^{p l}\right\}$ are total strain vector, elastic strain vector, thermal strain vector and plastic strain vector, respectively. The simulation of plasticity is incorporated with yield criteria, flow rule and isotropic hardening rule. The yield criterion is used to predict initial yield expressed as a function of yield stress. In this study the von-Mises stress is considered as yield criterion, stated as:

$$
\sigma_{m}=\sqrt{\frac{\left(\sigma_{1}-\sigma_{2}\right)^{2}+\left(\sigma_{2}-\sigma_{3}\right)^{2}+\left(\sigma_{1}-\sigma_{3}\right)^{2}}{2}},
$$

where, $\sigma_{1}, \sigma_{2} \sigma_{3}$ are the three principal stresses from any point in the $\mathrm{x}, \mathrm{y}$, or $\mathrm{z}$ directions of the principal axis. The temperature dependent thermo-mechanical properties of stainless steel 304 considered in simulation are shown in Table 1.

\section{SOLUTION PROCEDURE}

The model is developed under the ANSYS pre-processor environment considering same dimensions as experiment.
The laser beam travels on X-Y plane while the penetration takes place along $\mathrm{Z}$ axis (Figure 1). The numerical simulation is done by applying sequentially coupled field analysis technique, where the outcomes of thermal analysis are considered as input load for structural analysis. Two different types of elements: SOLID70 and SOLID185 are considered for thermal and structural analysis, respectively. Both elements are eight nodded brick elements and mutually conversable. The details of these elements are illustrated at reference (Inc 2007). Due to involvement of high heat flux, finer mesh is considered along the laser path. While coarser elements are created in the neighbouring zone then the coarsest mesh is in the outer portion of the model as shown in Figure 2. As irradiated laser beam is circular, so only half of the laser beam is considered in the simulation. This will result in a slightly deviated temperature pattern from the real one by less than $1.50 \%$ (average) as shown in Figure 3, however, significant computational time up to 2 times is saved. Mesh density sensitivity is investigated to select the appropriate element size $0.022 \times 0.022 \mathrm{~mm}(\mathrm{X}-\mathrm{Y})$. Total number of elements and nodes of the proposed model are 407380 and 414380 , respectively.

Gaussian heat flux is formulated by using ANSYS APDL programming language (Yang et al. 2010). The movement of the heat flux vector is simulated by using a time varying multiple steps and local co-ordinate system (Nyon et al. 2012; Yilbas et al.2010). The process of material removal during laser cutting is simulated by using element death technique. In this technique, every time after the step elements temperature are tested and those elements which cross the melting temperature $\left(1450^{\circ} \mathrm{C}\right)$ are selected and deactivated by using EKILL command (i.e. making selected elements insignificant by changing the conductivity about to zero) (Inc 2007). Hence, the cutting edge temperature is remained about to melting point $\left(1450^{\circ} \mathrm{C}\right)$ of stainless steel-304.

Stainless steel-304 is austenitic and imbedded chromium turns in to chromium carbide at temperature $400-800^{\circ} \mathrm{C}$ which form HAZ. Thus the width of HAZ in

TABLE 1. Material property of stainless steel-304 (Lee \& Chen 2011; Shiue et al. 2004)

\begin{tabular}{cccccccc}
\hline Temp $\left({ }^{\circ} \mathrm{C}\right)$ & $\begin{array}{c}\text { Density } \\
\left(\mathrm{g} \mathrm{cm}^{-3}\right)\end{array}$ & $\begin{array}{c}\text { Conductivity } \\
\left(\mathrm{W} \mathrm{m}^{-1} \mathrm{~K}^{-1}\right)\end{array}$ & $\begin{array}{c}\text { Specific Heat } \\
\left(\mathrm{KJ} \mathrm{g}^{-1} \mathrm{~K}^{-1}\right)\end{array}$ & $\begin{array}{c}\text { Young's } \\
\text { modulus } \\
(\mathrm{GPa})\end{array}$ & $\begin{array}{c}\text { Poisson's } \\
\text { ratio }\end{array}$ & $\begin{array}{c}\text { Thermal expansion } \\
\text { coefficient } \\
\left(\alpha \times 10-6\left(\mathrm{~K}^{-1}\right)\right.\end{array}$ & $\begin{array}{c}\text { Yield } \\
\text { strength } \\
(\mathrm{MPa})\end{array}$ \\
\hline 30 & 7931 & 15.5 & 435 & 197.13 & 0.27 & 16.03 & 367 \\
100 & 7896 & 16.2 & 452 & 194.00 & 0.28 & 17.05 & 340 \\
200 & 7849 & 17.5 & 479 & 187.18 & 0.284 & 17.54 & 331 \\
300 & 7801 & 18.9 & 499 & 181.00 & 0.289 & 18.00 & 330 \\
400 & 7753 & 20.3 & 517 & 170.00 & 0.291 & 18.73 & 290 \\
500 & 7704 & 21.8 & 534 & 160.73 & 0.295 & 19.36 & 266 \\
600 & 7655 & 23.4 & 551 & 148.00 & 0.299 & 19.84 & 220 \\
800 & 7555 & 26.6 & 585 & 125.50 & 0.302 & 21.24 & 165 \\
1000 & 7453 & 29.8 & 622 & 69.20 & 0.305 & 23.49 & 66 \\
1200 & 7346 & 33.1 & 663 & 20.55 & 0.32 & 23.49 & 60 \\
1450 & 7249 & 36.3 & 865 & 8.84 & 0.32 & 23.49 & 60 \\
\hline
\end{tabular}

Latent Heat of melting $=2.6 \times 10^{5} \mathrm{Jkg}^{-1}$, Solidus Temperature $=1400^{\circ} \mathrm{C}$, Liquidus Temperature $=1450^{\circ} \mathrm{C}$ 


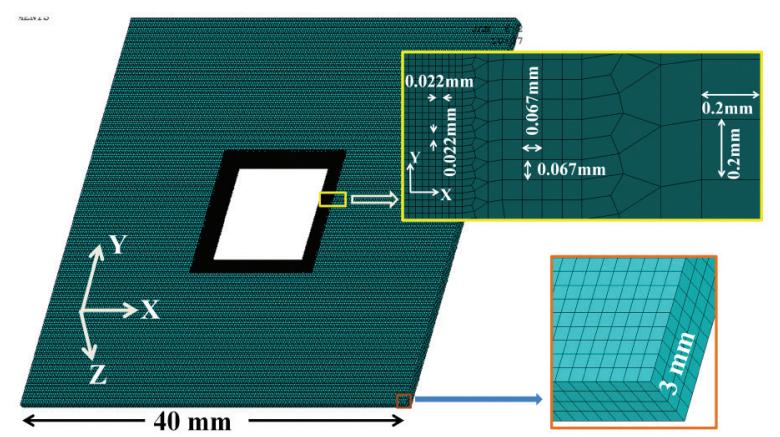

FIGURE 2. FEM model and mesh management

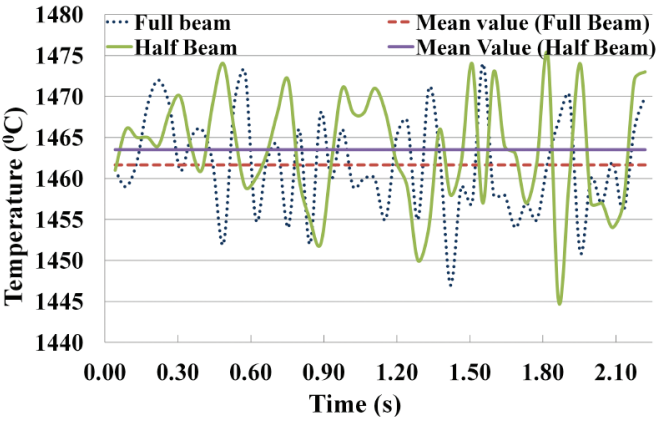

FIGURE 3. Maximum temperature along the cutting edge; comparison of full beam and half beam simulation is measured by distance-temperature relation considering $800^{\circ} \mathrm{C}$ as critical temperature (Sheng \& Joshi 1995). Physically the width of HAZ is measured in four locations (A, C, E G) by using optical microscope. The presence of carbide and microstructure analysis is done by XRD and SEM.

\section{RESULTS AND DISCUSSION}

In the present study an experimentally validated thermomechanical 3-D FEM model for laser cutting of square blanks in stainless steel-304 has been developed by ANSYS. The proposed simulation model was used to predict the thermal distribution, HAZ and thermal stress which develop during the blanking process. Moreover the effect of laser power and cutting speed on HAZ are analysed.

Laser cutting is a combine effect of heating, melting and molten material ejection. Thus in actual case temperature at the edge of kerf is found about to melting temperature (Nyon et al. 2012; Yilbas \& Akhtar 2011). Similar situation observed in proposed FEM simulation as shown in Figures 4 and 5. The maximum temperature of various point along the cutting edges are found about melting temperature of stainless steel-304, while laser beam reaches those points. The $3 \mathrm{D}$ view of temperature distribution is shown in Figure 4.

Figure 5 shows time varying temperature at different point (A,B,C,D,E,F,G,H) along the kerf, while laser power is 2160 watt and travelling at different speeds like 10, 15 and $20 \mathrm{~mm} / \mathrm{s}$. However, Figure 6 shows temperature distribution perpendicular to laser path along $\mathrm{X}$ and $\mathrm{Y}$ axis. It shows maximum temperature along the edge of kerf is independent on cutting speed. Only the rate of temperature increment and reduction are influenced by cutting speed. It is observed that the rate of temperature increment and reduction are increased with cutting speed. Because the rate of heat loss is fixed but laser-material interaction time varies with cutting speed.

Figure 7 shows 3-D view of von-Mises stress distribution at middle and end of cutting process. After the end of cutting the workpiece is allowed to cool down to atmospheric temperature. Figure 8 shows the temperature distribution along the circumference of upper surface (near the cutting edge) of square blank after the end of cutting i.e. at the beginning of cooling and at the end of cooling. Whereas, Figure 9 shows the corresponding von-Mises stress distribution. It shows that at the beginning of cooling the von-Mises stresses attain lower value. It is because

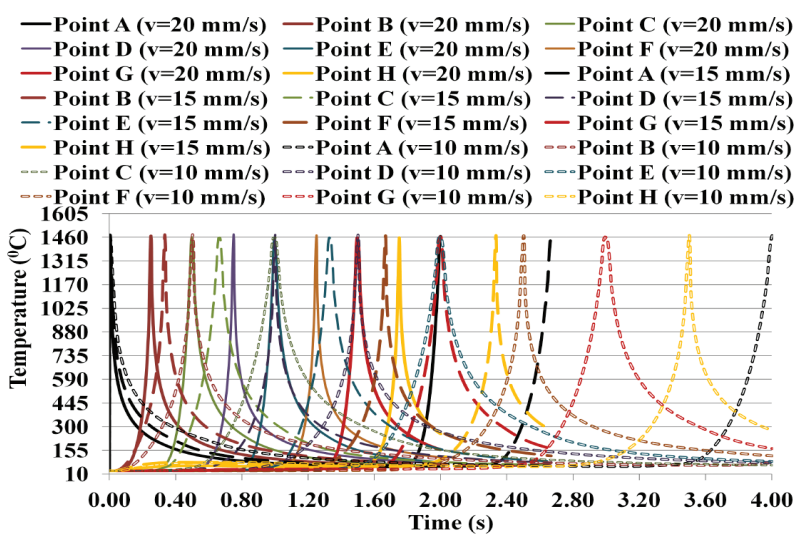

FIGURE 4. Temperature profile at different time (a) $1.00 \mathrm{~s}$ and (b) $2.00 \mathrm{~s}$; laser power 2160 watt, speed $20 \mathrm{~mm} / \mathrm{s}$ 


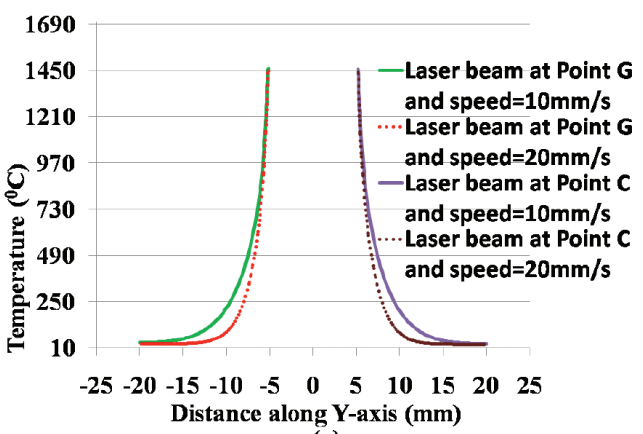

(a)

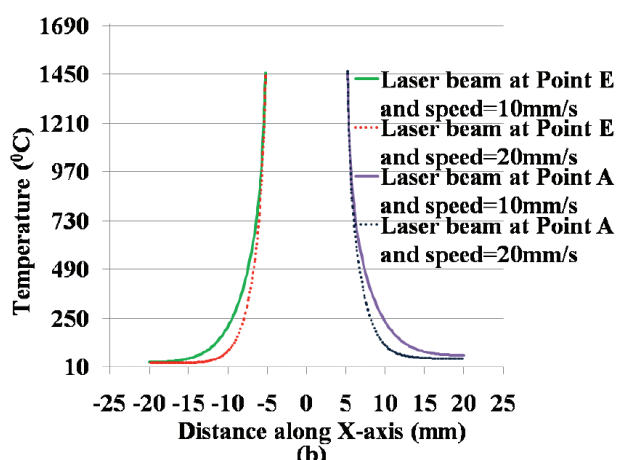

(b)

FIGURE 5. Time dependent temperature graph at different point along the cutting edge; laser power 2160 watt; thickness $3 \mathrm{~mm}$
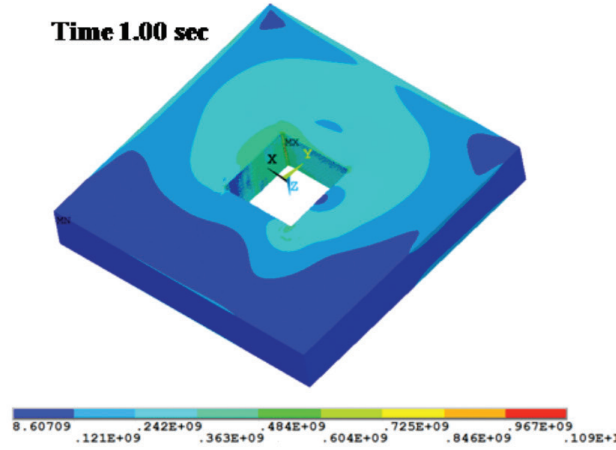

(a)

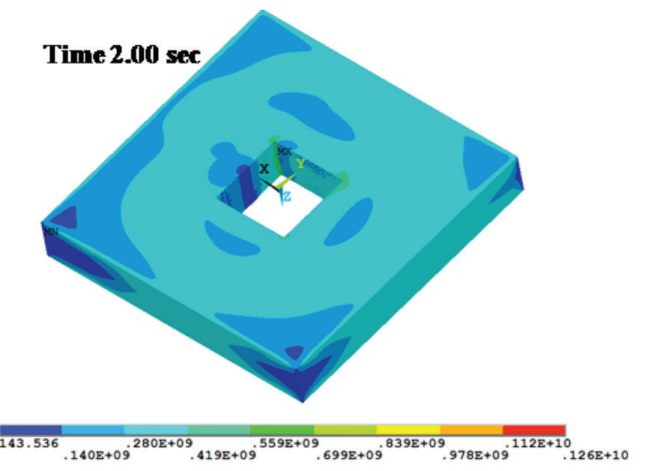

(b)

FIGURE 6. (a) Temperature distribution along Y-axis; heat source at point $\mathrm{G}$ and $\mathrm{C}$, (b) Temperature distribution along $\mathrm{X}$-axis ; heat source at point $\mathrm{E}$ and $\mathrm{A}$; Laser power 2160 watt, thickness $3 \mathrm{~mm}$

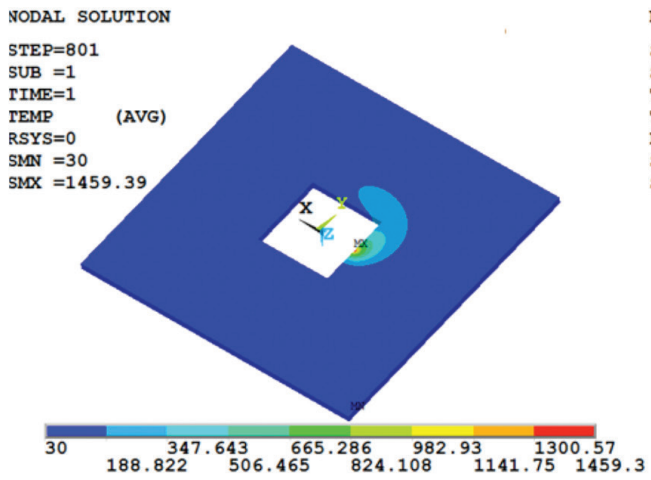

(a)

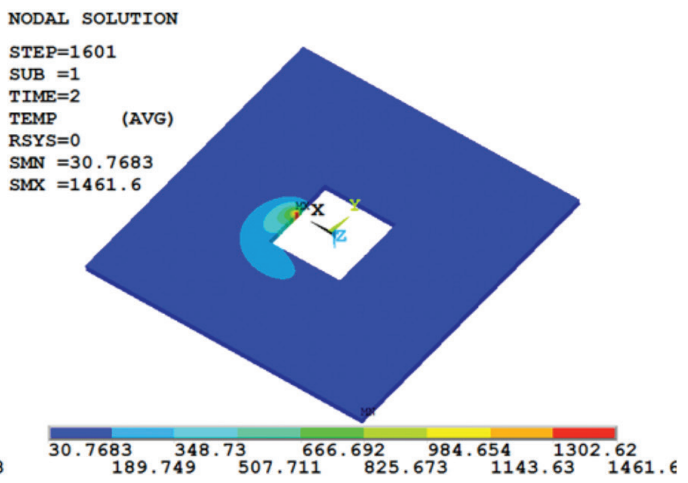

(b)

FIGURE 7. von-Mises stress profile at different time (a) $1.00 \mathrm{~s}$ and (b) $2.00 \mathrm{~s}$; laser power 2160 watt, speed $20 \mathrm{~mm} / \mathrm{s}$

of temperature dependent young's modulus (Table 1) considered in simulation which is low at high temperature. Furthermore, the maximum von-Mises stress is developed at the corner of the cutting edge. Because, the corners are fixed and associated with high temperature, which cause high thermal expansion.

As maximum stress is developed at the corner of the square blank, each corner has experienced almost the same amount of stress. Hence, one of the corner points (near point-D) and its neighbor points (near point-C and point-E) are considered for further analysis. Figure 10 shows the temporal variation of von-Mises stress of point C, D, E at different cutting speeds. It shows von-Mises stress increases sharply due to rapid decay of temperature after reaching the maximum temperature (Figure 6). Once the lower temperature is achieved after cooling, the stress 


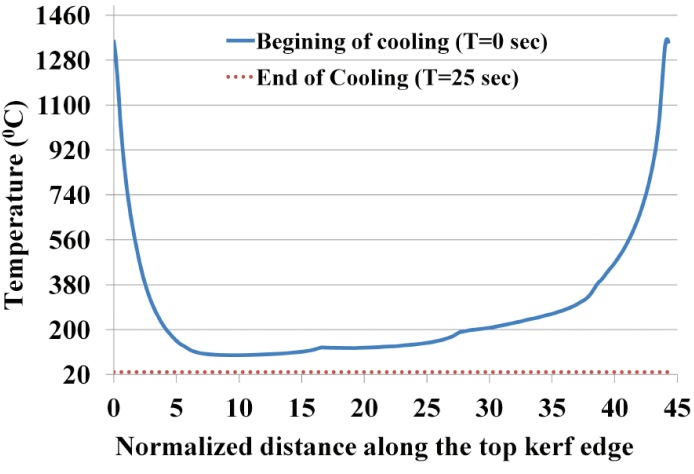

FIGURE 8. Temperature distribution along the upper circumference of square blanks (near the cutting edge); laser power 2160 watt, cutting speed $20 \mathrm{~mm} / \mathrm{s}$

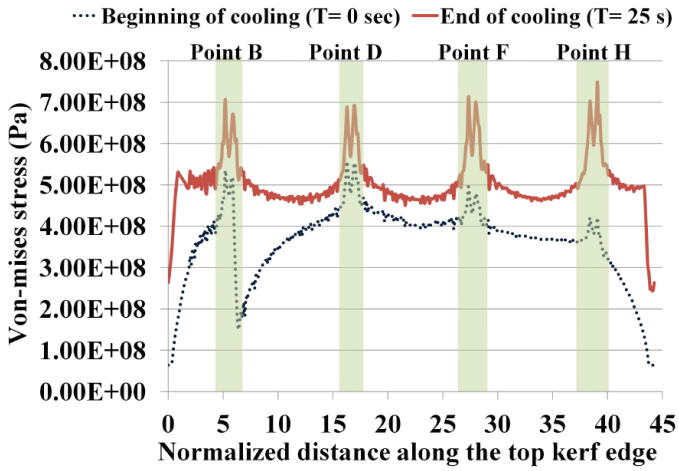

FIGURE 9. von-Mises stress distribution along the upper circumference of square blanks (near the cutting edge);

laser power 2160 watt, cutting speed $20 \mathrm{~mm} / \mathrm{s}$

level becomes almost steady with time progression; which is called as residual stress. The values of residual stress at point $\mathrm{C}, \mathrm{D}$ and $\mathrm{E}$ are found as $420,550,425 \mathrm{MPa}$, respectively, which have crossed the elastic limit (360 $\mathrm{MPa}$ ) of stainless steel-304. Hence cracks, surface defects are formed at those areas. This is supported by SEM results as shown in Figure 11.

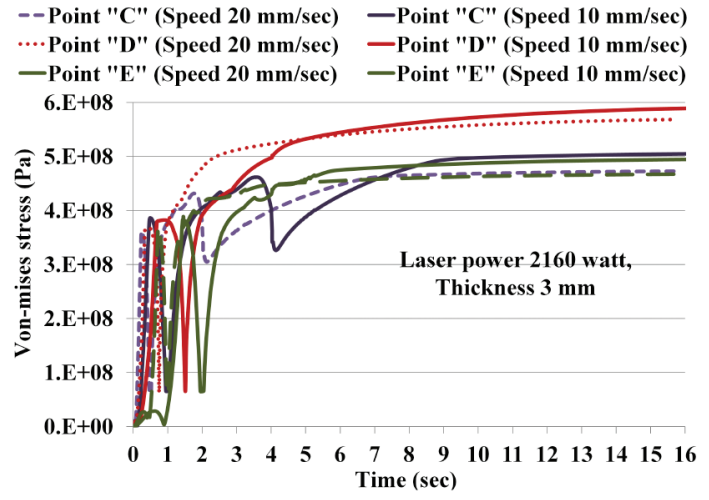

FIGURE 10. Temporal variation of Von-mises stress at different speed; laser power 2160 watt

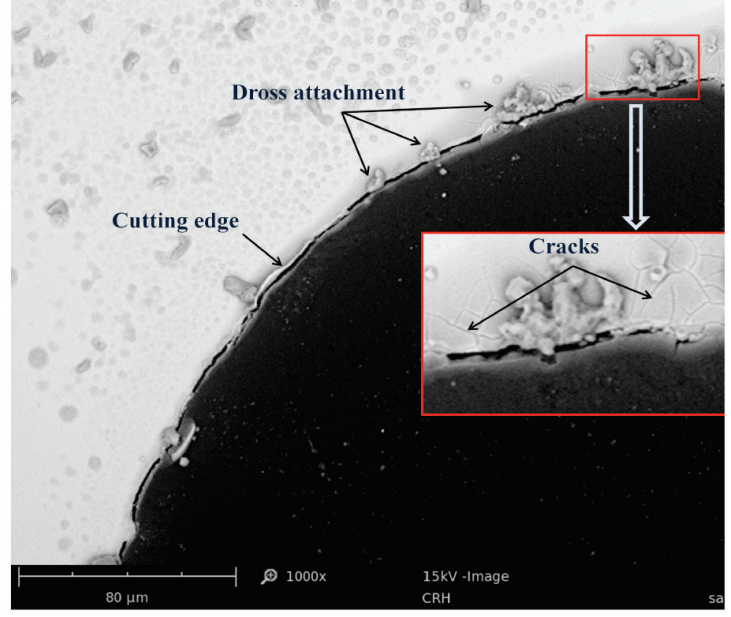

FIGURE 11. SEM analysis at cutting edge

\section{HEAT AFFECTED ZONE (HAZ) ANALYSIS}

After laser blanking, the cutting samples are etched and metallurgical changes are examined under optical microscope. The comparison of simulation and experimental results are presented in Figure 12, while the laser power is 2160 watt and travelling at $10 \mathrm{~mm} / \mathrm{s}$. However the presence of chromium carbide, chromium sulphide, nickel carbide and nickel sulphide are identified by XRD.

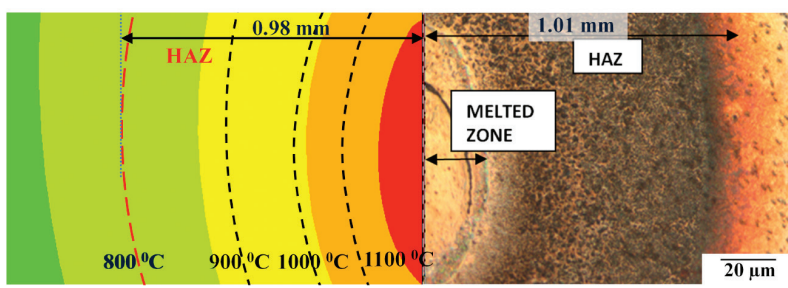

FIGURE 12. Comparison of width HAZ in experiment and simulation; Laser power 2160 watt, cutting speed $10 \mathrm{~mm} / \mathrm{s}$

In this study, a total of nine experiments were conducted. The results of HAZ measured from experiment and simulation are compared with each other as shown in Table 2. There is a good relation in experimental and simulation results as relative error lies $>8.2 \%$. It is also found that the experimental value is little higher than the simulation results. This is because of the coarseness element size.

A parametric study is done to understand the effects of laser power and cutting speed on width of HAZ formation. The width of HAZ increases with the increase of laser power due to high beam intensity (Figure 13). On the other hand, with the increase of cutting speed, the width of HAZ decreases due to reduction of laser material interaction time (Figure 13).

The results of ANOVA are shown in Table 3. As the value of $\mathrm{F}$ for laser power and speed are more than 19.00 at significance level 0.05. Thus both laser power and speed are significant in this study (Dinov 2014). 
TABLE 2. Results of width of HAZ

\begin{tabular}{|c|c|c|c|c|c|c|c|c|c|}
\hline \multicolumn{2}{|c|}{ Input variables } & \multicolumn{6}{|c|}{ Width of HAZ } & \multirow{3}{*}{$\begin{array}{c}\text { Absolute } \\
\text { error }\end{array}$} & \multirow{3}{*}{$\begin{array}{l}\text { Relative } \\
\text { error (\%) }\end{array}$} \\
\hline \multirow{2}{*}{$\begin{array}{l}\text { Power } \\
\text { (watt) }\end{array}$} & \multirow{2}{*}{$\begin{array}{l}\text { Speed } \\
(\mathrm{mm} / \mathrm{s})\end{array}$} & \multicolumn{5}{|c|}{ Experiment $(\mu \mathrm{m})$} & \multirow{2}{*}{$\begin{array}{l}\text { Simulation } \\
\qquad(\mu \mathrm{m})\end{array}$} & & \\
\hline & & $1 \mathrm{st}$ & $2 \mathrm{nd}$ & $3^{\text {rd }}$ & 4 th & Mean & & & \\
\hline 2160 & 10 & 1005 & 1012 & 1013 & 1010 & 1010 & 980 & 30 & 2.97 \\
\hline 2160 & 15 & 980 & 980 & 985 & 975 & 980 & 900 & 80 & 8.16 \\
\hline 2160 & 20 & 870 & 870 & 875 & 865 & 870 & 850 & 20 & 2.30 \\
\hline 1800 & 10 & 946 & 936 & 939 & 939 & 940 & 900 & 40 & 4.26 \\
\hline 1800 & 15 & 900 & 910 & 890 & 900 & 900 & 878 & 22 & 2.44 \\
\hline 1800 & 20 & 850 & 850 & 850 & 850 & 850 & 800 & 50 & 5.88 \\
\hline 1440 & 10 & 850 & 860 & 840 & 850 & 850 & 800 & 50 & 5.88 \\
\hline 1440 & 15 & 805 & 805 & 810 & 810 & 800 & 755 & 45 & 5.63 \\
\hline 1440 & 20 & 766 & 752 & 762 & 760 & 760 & 720 & 40 & 5.26 \\
\hline
\end{tabular}
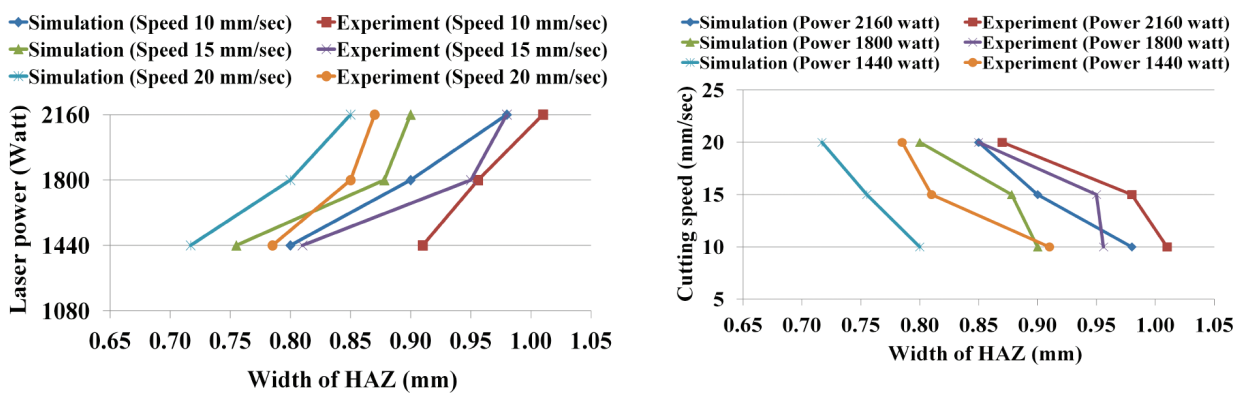

FIGURE 13. Effect of laser power and cutting speed on width of HAZ

TABLE 3. ANOVA table for width of HAZ

\begin{tabular}{lccccc}
\hline Factor & Sum of square & DOF & Variance & F ratio & Percent of contribution \\
\hline Power & 137688.89 & 2 & 68844.44 & 39.02 & 64.21 \\
Speed & 69688.89 & 2 & 34844.44 & 19.75 & 32.50 \\
Error & 7057.11 & 4 & 1764.28 & & 3.29 \\
Total & 214434.90 & 8 & & & \\
\hline
\end{tabular}

But laser power is more significant parameter $(64.21 \%)$ than cutting speed $(32.5 \%)$.

\section{CONCLUSION}

In this study, an experimentally validated thermomechanical model of laser blanking of square samples is developed by using ANSYS. The thermal distribution along the cutting edges shows that the maximum temperature at the cutting edge is independent of laser power and speed. Only cutting speed has some significant impact on rate of temperature increment and reduction. Maximum stress is observed at the corner; while it crosses the yield limit it causes cracks. These finding is supported by SEM, as most of the cracks, surface defects are attainted along the cutting edge and which are pronounced at the corner. The metallurgical changes and formation of carbide, sulphide causes the HAZ. The experimental results of width of HAZ show good agreement with simulation results (relative error $<10 \%)$. The parametric studies indicate that with the increase of laser power and decrease of cutting speed the width of HAZ increase. However, the results of ANOVA suggested that laser power is the most significant parameter having $64.21 \%$ of contribution to width of HAZ.

\section{ACKNOWLEDGEMENTS}

Financial and technical supports from the Department of Mechanical Engineering, Faculty of Engineering, University of Malaya and grant RP010C-13AET (UMRG) are gratefully acknowledged.

\section{REFERENCES}

Anderson, M.C. \& Shin, Y.C. 2006. Laser-assisted machining of an austenitic stainless steel: P550. Proceedings of the Institution of Mechanical Engineers, Part B: Journal of Engineering Manufacture 220(12): 2055-2067.

Boyden, S. \& Zhang, Y. 2006. Temperature and wavelengthdependent spectral absorptivities of metallic materials in the infrared. Journal of Thermophysics and Heat Transfer 20(1): 9-15. 
Dinov, I. 2014. Statistics Online Computational Resource (SOCR). Available from http://www.socr.ucla.edu/applets. dir/f table.html.

Guenael, G., Morel, F., Lebrun, J-L. \& Morel, A. 2007. Machinability and surface integrity for a bearing steel and a titanium alloy in laser assisted machining (optimisation on LAM on two materials). Lasers in Engineering 17(5): 329-344.

Inc. 2007. ANSYS. ANSYS Theory Manual, Release 11

Jamshidi Aval, H., Farzadi, A., Serajzadeh, S. \& Kokabi, A.H. 2009. Theoretical and experimental study of microstructures and weld pool geometry during GTAW of 304 stainless steel. The International Journal of Advanced Manufacturing Technology 42(11-12): 1043-1051. doi: 10.1007/s00170008-1663-6.

Khan, O.U. \& Yilbas, B.S. 2004. Laser heating of sheet metal and thermal stress development. Journal of Materials Processing Technology 155: 2045-2050.

Lee, H.T. \& Chen, C.T. 2011. Numerical and experimental investigation into effect of temperature field on sensitization of AISI 304 in butt welds fabricated by gas tungsten arc welding. Materials Transactions 52(7): 1506-1514.

Masumoto, I., Shinoda, T. \& Hirate, T. 1990. Weld decay recovery by laser beam surfacing of austenitic stainless steel welded joints. Transactions of the Japan Welding Society 21(1): 11-17.

Mazumder, J. \& Steen, W.M. 1980. Heat transfer model for CW laser material processing. Journal of Applied Physics 51(2): 941-947.

Nyon, K.Y., Nyeoh, C.Y., Mohzani Mokhtar \& Razi AbdulRahman. 2012. Finite element analysis of laser inert gas cutting on Inconel 718. The International Journal of Advanced Manufacturing Technology 60(9-12): 995-1007.

Parandoush Pedram \& Altab Hossain. 2014. A review of modeling and simulation of laser beam machining. International Journal of Machine Tools and Manufacture 85: 135-145.

Sheng, P.S. \& Joshi, V.S. 1995. Analysis of heat-affected zone formation for laser cutting of stainless-steel. Journal of Materials Processing Technology 53(3-4): 879-892. doi: 10.1016/0924-0136(94)01761-O.

Shiue, R.K., Chang, C.T., Young, M.C. \& Tsay, L.W. 2004. The effect of residual thermal stresses on the fatigue crack growth of laser-surface-annealed AISI 304 stainless steel: Part I: computer simulation. Materials Science and Engineering: A 364(1): 101-108.

Steen, W.M., Mazumder, J. \& Watkins, K.G. 2003. Laser Material Processing. New York: Springer.

Tan, C.W., Chan, Y.C., Leung, B.N.W., Tsun, J., \& So, A.C.K. 2005. Characterization of Kovar-to-Kovar laser welded joints and its mechanical strength. Optics and Lasers in Engineering 43(2): 151-162.
Yang, J., Sun, S., Brandt, M. \& Yan, W. 2010. Experimental investigation and 3D finite element prediction of the heat affected zone during laser assisted machining of Ti6Al4V alloy. Journal of Materials Processing Technology 210(15): 2215-2222. doi: http://dx.doi.org/10.1016/j. jmatprotec.2010.08.007.

Yilbas, B.S. \& Akhtar, S.S. 2011. Laser cutting of alloy steel: Three-dimensional modeling of temperature and stress fields. Materials and Manufacturing Processes 26(1): 104-112. doi: 10.1080/10426914.2010.501092.

Yilbas, B.S., Akhtar, S. \& Keles, O. 2014. Laser cutting of triangular blanks from thick aluminum foam plate: Thermal stress analysis and morphology. Applied Thermal Engineering 62(1): 28-36. doi: http://dx.doi.org/10.1016/j. applthermaleng.2013.09.026.

Yilbas, B.S., Arif, A.F.M. \& Abdul Aleem, B.J. 2010. Laser cutting of rectangular blanks in thick sheet steel: Effect of cutting speed on thermal stresses. Journal of Materials Engineering and Performance 19(2): 177-184.

Yilbas, B.S., Arif, A.F.M. \& Abdul Aleem, B.J. 2009. Laser cutting of holes in thick sheet metals: Development of stress field. Optics and Lasers in Engineering 47(9): 909-916. doi: http://dx.doi.org/10.1016/j.optlaseng.2009.03.002.

Yilbas, B.S., Davies, R. \& Yilbas, Z. 1990. Study into the measurement and prediction of penetration time during $\mathrm{CO} 2$ laser cutting process. Proceedings of the Institution of Mechanical Engineers, Part B: Journal of Engineering Manufacture 204(2): 105-113.

Yusoff Nukman, Saifu R. Ismail, Azuddin Mamat \& Aznijar Ahmad-Yazid. 2008. Selected Malaysian wood $\mathrm{CO}_{2}$-laser cutting parameters and cut quality. American Journal of Applied Sciences 5(8): 990-996.

A.M. Sifullah, Y. Nukman*, M.A. Hassan \& A. Hossain Department of Mechanical Engineering Faculty of Engineering, University of Malaya 50603 Kuala Lumpur, Federal Territory Malaysia

Khaled I. Ahmed

Mechanical Engineering Department

Assiut University, Assiut 71615

Egypt

*Corresponding author; email: nukman@um.edu.my

Received: 9 March 2016

Accepted: 17 October 2016 